\title{
GAGASAN PENGATURAN HUKUM PEMERIKSAAN PERSEROAN TERBATAS (Suatu Evaluasi Normatif terhadap Pasal 138 - Pasal 141 Undang- Undang Nomor 40 Tahun 2007 tentang Perseroan Terbatas)
}

\author{
Muhammad Syaifuddin \\ Fakultas Hukum Universitas Sriwijaya \\ E-mail: syaifuddin_unsri@yahoo.co.id
}

\begin{abstract}
Law No. 40 Year 2007 oblige good corporate governance. Practically, there is a chance to do wrongful act which cause bad corporate governance. Law No. 40 Year 2007 have some legal inconsistencies, so that cause uncertainty and unused legal practically. The idea of regulating on investigating of a company in forward has to develop of strengthening of legal certainty principle and legal utility principle (besides legal justice principle) which concrete in positive legal norms about performing, governing, investigating and post-investigating of a limited company by shares as a system. Then, the revising of positive legal norms about investigating of a limited company by shares consistently, which refers to the logics of legal rules.
\end{abstract}

Keywords: the investigating, limited company by shares, normative evaluation, legal inconsistency.

\begin{abstract}
Abstrak
UU No 40 Tahun 2007 mewajibkan good corporate governance, namun secara praktis, ada kesempatan untuk melakukan tindakan yang salah yang menyebabkan corporate governance yang buruk. UU No 40 Indonesia Tahun 2007 memiliki beberapa inkonsistensi hukum, sehingga menyebabkan ketidakpastian hukum dan ketidakmanfaatan hukum praktis. Gagasan untuk mengatur penyelidikan perusahaan pada masa mendatang harus mengembangkan dan menguatkan prinsip kepastian hukum dan prinsip kemanfaatan hukum (selain prinsip keadilan hukum) yang konkrit dalam norma-norma hukum positif tentang melakukan, mengatur, menyelidiki dan pasca-menyelidiki sebuah perusahaan dibatasi oleh saham sebagai sebuah sistem. Kemudian merevisi norma hukum positif tentang menyelidiki sebuah perusahaan dibatasi oleh saham, yang mengacu pada logika aturan hukum.
\end{abstract}

Kata kunci: penyelidikan, pembatasan perusahaan oleh saham, evaluasi normatif, inkonsistensi hukum.

\section{Pendahuluan}

Perseroan terbatas (selanjutnya disingkat PT), adalah badan hukum yang merupakan persekutuan modal, didirikan berdasarkan perjanjian, melakukan kegiatan usaha dengan modal dasar yang seluruhnya terbagi dalam saham dan memenuhi persyaratan yang ditetapkan dalam UU No. 40 Tahun 2007 tentang Perseroan Terbatas serta peraturan pelaksanaannya (vide Pasal 1). ${ }^{1}$

\footnotetext{
Lihat dan bandingkan pengertian PT ini dengan beberapa pendapat yang berkaitan dengan masing-masing unsur yang ada di PT, pada Ridwan Khairandy, "Perseroan Terbatas sebagai Badan Hukum", Jurnal Hukum Bisnis, Vol. 26 No. 3 Tahun 2007, hlm. 5; Yuniarti, "Kewenangan Notaris Membuat Akta Risalah Rapat Umum Pemegang Saham Luar Biasa tentang Perubahan Ang-
}

UU No. 40 Tahun 2007 telah memuat pengaturan hukum pengelolaan perusahaan yang baik, yang lebih dikenal dengan istilah good corporate governance (disingkat GCG). ${ }^{2}$ Namun,

garan Dasar Perseroan Terbatas", Repertorium, Vol. 1 No. 1 Mei-September 2010, hlm. 50; Habib Adjie, "Tanggung Jawab Sosial Perusahaan", Jurnal Hukum Bisnis, Vol. 27-No. 1-Tahun 2008, hlm. 60; dan M. Yahya Harahap, "Separate Entity, Limited Liability, dan Piercing the Corporate Veil", J urnal Hukum Bisnis, Vol. 26-No. 3-Tahun 2007, hlm. 44.

2 GCG, menurut The Organization for Economic Corporation and Development, adalah sistem pengendalian perusahaan, mencakup pembagian tugas, hak dan kewajiban mereka yang berkepentingan terhadap perusahaan, termasuk para pemegang saham, dewan pengurus, para manajer, dan semua anggota the stakeholder nonpemegang saham. Lihat dalam Camelia Malik, "Implikasi Adanya Komisaris Independen dalam Perseroan Berdasarkan UU No. 40 Tahun 2007", J urnal Hukum 
secara praktikal, terbuka kesempatan untuk terjadinya praktik penyimpangan, yang dapat menjadikan pengelolaan $\mathrm{PT}^{3}$ tidak baik (dalam makna tidak transparan, tidak akuntabel, tidak adil, dan tidak responsibel), sehingga UU No. 40 Tahun 2007 telah mengatur pemeriksaan terhadap PT, khususnya dalam Pasal 138 sampai dengan Pasal 141, sebagai bentuk dan mekanisme pengawasan represif-eksternal terhadap pengelolaan PT.

Pemeriksaan PT berdasarkan UU No. 40 Tahun 2007 dalam spirit menjamin kepastian hukum, sehingga seharusnya tidak ada normanorma hukumnya yang inkonsisten, karena inkonsistensi hukum, menurut M. Isnaeni, menampakkan citra yang tidak pasti, sehingga sulit menciptakan kepastian hukum sebagai sendi utama dari aturan hukum selain keadilan, yang berkait-an erat dengan efisiensi ekonomi, yang seringkali menggunakan jasa hukum dalam pelbagai transaksi ekonominya. ${ }^{4}$ Selain itu, pemeriksaan PT menurut UU No. 40 Tahun 2007 juga seharusnya mengeliminasi kemenduaan hukum, karena hukum - menurut Satjipto Rahardjo - seringkali mengandung kemenduaan (ambiguity) sebagai cacat logisnya, yaitu: pertama, kemenduaan semantik, karena kata-kata yang dirumuskan secra umum (open texture); kedua, kemenduaan sintaktik, karena kata-kata "atau", "dan", "semua", dan sebagainya; dan ketiga, kemenduaan karena pernyataan maksud pembuat undang-undang sendiri tidak dikonseptualisasikan secara jelas. ${ }^{5}$

Bisnis, Volume 26-No. 3 Tahun 2007, hlm. 31. Bandingkan pula dengan J immy E. Alias, "Peran Manajemen Risiko Strategik dalam Mendukung Good Corporate Governance", Jurnal Hukum Bisnis, Volume 23-No. 3Tahun 2004, hlm. 52.

3 Istilah "pengelolaan PT" bermakna luas, mencakup pengarahan PT (yang merupakan wewenang RUPS), pengurusan PT (yang merupakan wewenang direksi), dan pengawasan PT (yang merupakan wewenang dewan komisaris. Lihat dalam Nindyo Pramono, "Tanggung Jawab Dan Kewajiban Pengurus PT (Bank) Menurut UU No. 40 Tahun 2007 Tentang Perseroan Terbatas", Buletin Hukum Perbankan dan Kebangsentralan, Vol. 05 Nomor 03, Desember 2007, hlm. 20-25.

4 M. Isnaeni, "Hak Tanggungan sebagai Lembaga Jaminan dalam Kerangka Tata Hukum Indonesia", J urnal Hukum Ekonomi, Edisi V, Agustus 1996, hlm. 2.

5 Satjipto Rahardjo, 2000, IImu Hukum, Bandung: PT. Citra Aditya Bakti, Bandung, h/m. 98.; Muhammad Syaifuddin, "Perspektif Global Penyelesaian Sengketa
Secara dogmatik, UU No. 40 Tahun 2007 seharusnya tidak memuat norma-norma hukum yang inkonsisten dan mendua, sehingga tidak menghambat spirit menjamin kepastian hukum (serta keadilan dan kemanfaatan) dalam pemeriksaan PT. Oleh karena itu, penting dikaji: pertama, bagaimanakah pengaturan hukum pemeriksaan PT dalam UU No. 40 Tahun 2007 dalam upaya mewujudkan pengelolaan perusahaan yang baik?; kedua, apakah ada atau tidak ada inkonsistensi dan kemenduaan hukum sebagai wujud kelemahan pengaturan hukum pemeriksaan PT dalam UU No. 40 Tahun 2007 yang dapat menjadi hambatan (constrain) dalam upaya mewujudkan pengelolaan perusahaan yang baik tersebut?; ketiga, bagaimanakah gagasan pengaturan hukum ideal pemeriksaan PT sebagai upaya mewujudkan pengelolaan perusahaan yang baik di masa yang akan datang.

\section{Pembahasan \\ Alasan dan Tujuan Pemeriksaan Perseroan Terbatas}

Menurut Pasal 138 ayat (1) UU No. 40 Tahun 2007, alasan pengajuan permohonan pemeriksaan PT kepada pengadilan, adalah terdapat "dugaan" (vermoeden, presumption): Pertama, PT melakukan perbuatan melawan hukum sebagai bentuk penyimpangan yang sifatnya melanggar norma larangan dan/atau tidak melaksanakan norma kewajiban dalam UU No. 40 Ta-hun 2007, peraturan hukum positif lainnya, dan anggaran dasar, yang menimbulkan kerugian bagi pemegang saham atau pihak ketiga; atau kedua, anggota direksi atau dewan komisaris sebagai personel (individual) dari organ-organ PT melakukan perbuatan melawan hukum yang merugikan PT atau pemegang saham atau pihak ketiga. Dengan demikian, terdapatnya dugaan terjadinya perbuatan melawan hukum sebagai bentuk penyimpangan dalam pengelolaan PT yang dilakukan oleh "karyawan yang tidak termasuk organ PT atau personel (individual) dari organ-organ PT", misal-

Investasi di Indonesia", De Jure, Jurnal Syariah dan Hukum, Vol. 02 Nomor 01, J uni 2010, hlm. 29. 
nya orang yang bekerja di bagian administrasi dan keuangan, tidak dapat dijadikan alasan pengajuan permohonan pemeriksaan PT, karena UU No. 40 Tahun 2007 tidak mengatur penyelesaian hukum individual dan konkritnya.

"Perbuatan melawan hukum" yang dilakukan oleh organ-organ PT, dalam hal ini RUPS, ${ }^{6}$ direksi ${ }^{7}$ dan dewan komisaris, ${ }^{8}$ baik secara organisasional (organ PT) maupun individual (personel dari direksi atau dewan komisaris sebagai organ PT), sebagai bentuk penyimpangan dalam pengelolaan PT sebagaimana di maksud Pasal 138 ayat (1) UU No. 40 Tahun 2007, adalah perbuatan melawan hukum (onrechtmatigedaad) menurut Pasal 1365 Kitab Undang-Undang Hukum Perdata (selanjutnya disingkat KUH Perdata) dan Yurisprudensi Arrest Lindenbaum-Cohen tahun 1919 H.R. 31 Januari, ${ }^{9}$ yaitu perbuatan yang bertentangan dengan UU No. 40 Tahun 2007 dan peraturan hukum positif lainnya, serta perbuat-an yang melanggar ketertiban umum dan kesusi-laan. Selain itu, juga mencakup perbuatan yang bertentangan dengan anggaran dasar $\mathrm{PT},{ }^{10}$ yang merupakan bagian dari isi akta pendirian PT (vide Pasal 8 ayat (1) UU No. 40 Tahun 2007), yang memuat norma-norma hukum positif yang wajib dipatuhi oleh RUPS, direksi dan dewan komisaris, baik secara organisasional (organ PT) maupun individual (personel dari organ PT). Jika dugaan terjadinya perbuatan melawan hukum terbukti, maka berdasarkan RUPS, direksi dan/atau dewan komisaris, baik secara organisasional (organ PT) maupun individual (personel

6 Lihat penjelasan lebih lanjut tentang RUPS ini pada Fred B.G. Tumbuan, Tugas dan Wewenang Organ Perseroan Terbatas Menurut Undang-Undang Tentang Perseroan Terbatas, PPH Newsletters, Nomor 70, September 2007, hlm. 17-18

7 Lihat dan bandingkan pembahasan tentang direksi dalam Nindyo Pramono, op.cit, hlm. 15-18.

8 Lihat mengenai pembahasan dewan direksi ini dalam Fred B.G. Tumbuan, op.cit, hlm. 22-24.

9 Baca lebih Ianjut mengenai Arrest Lindenbaum-Cohen ini pada Mariam Darus Badruzzaman, 2001, Kompilasi Hukum Peri-katan, Bandung: PT. Citra Aditya Bakti, hlm. 106-107; dan Fred B.G., op.cit, hlm. 21.

10 Lihat penjelasan tentang anggaran dasar PT pada Muhammad Syaifuddin, "Tanggung J awab Sosial Perusahaan: Perkembangan Teori dan Relevansinya dengan Tuj uan Hukum Perusahaan", Simbur Cahaya, No. 31 Tahun XI, Mei 2006, hlm. 232. dari direksi atau dewan komisaris sebagai organ PT) wajib mengganti kerugian kepada pemegang saham atau pihak ketiga atau bahkan kejaksaan yang hak atau kepentingannya dirugikan. Alasan pengajuan permohonan pemeriksaan PT kepada pengadilan menurut Pasal 138 ayat (1) UU No. 40 Tahun 2007 pada dasarnya adalah suatu "kepentingan hukum"11 atau posita yang berisi "alasan hukum" ${ }^{12}$ yang mendasari "permohonan" (bukan gugatan) pemeriksaan PT oleh pemegang saham dan pihak ketiga.

Tujuan pemeriksaan PT dinyatakan secara sumir dalam UU No. 40 tahun 2007. Berdasarkan tafsir teleologis atas kalimat "...-dengan tujuan untuk mendapatkan data atau keterangan dalam hal terdapat dugaan..." dalam norma hukum pada Pasal 138 ayat (1) UU No. 40 Tahun 2007, dapat dipahami bahwa pemeriksaan PT bertujuan menemukan dan menerang benderangkan kebenaran (mengungkapkan kebe-naran menjadi terang-benderang) yang didukung oleh data atau keterangan sebagai bukti yang bersifat langsung (direct evidence) yang mampu membuktikan terjadinya perbuatan melawan hukum sebagai bentuk penyimpangan dalam pengelolaan PT.

Secara metodelogis, upaya menemukan dan menerang-benderangkan kebenaran harus menggunakan penalaran hukum yang mengikuti prinsip-prinsip logika yang disebut silogisme. ${ }^{13}$ Ini berarti bahwa upaya menemukan dan menerangkan kebenaran harus didasarkan atas fakta-fakta hukum (premis minor/ statement of fact) yang diperoleh selama proses pemeriksaan PT dilakukan. Jika fakta-fakta hukum yang ditemukan memenuhi unsur-unsur perbuatan melawan hukum sebagai bentuk penyimpangan dalam pengelolaan PT sebagaimana dimaksud

11 Baca mengenai makna kepentingan hukum pada Sudikno Mertokusumo, 2006, Hukum Acara Perdata Indonesia, Yogyakarta: Liberty, hlm. 82-84; dan Radian Salman, SH, LL. M, Mahkamah Konstitusi dan Politik Hukum di Bidang Pemilihan Umum, Jurnal Konstitusi, Vol. II, No. 1 , J uni 2009, hal 91.

12 Lihat mengenai maksud dari alasan hukum pada M. Yahya Harahap. op.cit., hlm. 532.

13 Penjelasan lebih lanjut mengenai silogisme dapat dibaca pada J ohnny Ibrahim, 2005, Teori dan Metode Penelitian Hukum Normatif, Malang: Bayu Media Publishing, hlm. 196. 
oleh Pasal 138 ayat (1) UU No. 40 Tahun 2007 (premis may-or/statement of law), maka hasil pemeriksaannya harus menegaskan bahwa benar terjadi perbuatan melawan hukum sebagai bentuk penyimpangan dalam pengelolaan PT (conclusion). J ika sebaliknya, maka hasil pemeriksaannya harus menegaskan bahwa tidak benar terjadi perbuatan melawan hukum sebagai bentuk penyimpangan dalam pengelolaan PT.

Tujuan pemeriksaan PT yang dinyatakan dalam Pasal 138 ayat (1) UU No. 40 Tahun 2007, adalah tujuan khusus atau mikro, yang secara sistemik dapat mendukung tujuan umum atau makro dari pemeriksaan PT, yaitu mewujudkan asas-asas hukum GCG dalam UU No. 40 Tahun 2007. ${ }^{14}$ Asas-asas itu meliputi pertama, asas transparansi, yang mengharuskan informasi perusahaan jelas, konsisten, dan dapat diperbandingkan, agar pihak-pihak yang berkepentingan dapat memerhitungkan dampak risiko bertransaksi dengan perusahaan (Pasal 66-Pasal 99); kedua, asas akuntabilitas, yang mengharuskan agency problem antara direksi dan pemegang saham, didasarkan pada sistem internal checks and balances yang mencakup praktik audit yang sehat dan pengawasan efektif berdasarkan keseimbangan antara pemegang saham, komisaris, dan direksi (Pasal 120-Pasal 121); ketiga, asas keadilan, yang mengharuskan perlindungan hak-hak pemegang saham minoritas dari keputusan direksi atau pemegang saham mayoritas yang merugikan kepentingannya atau kepentingan secara keseluruhan (Pasal 61); dan keempat, asas responsibilitas, yang mengharuskan perusahaan mempunyai tanggung jawab mematuhi hukum yang berlaku (Pasal 2). Untuk mencapai manfaat yang optimal, pengelola perusahaan perlu menjabarkan

14 Lihat penjelasan mengenai asas-asas GCG ini pada Muhammad Syaifuddin, "Wewenang Dewan Komisaris Mengurus Perseroan Terbatas: Analisis Rasio dan Implikasi Hukum Pasal 118 dalam Kaitannya dengan Pasal 1 angka 6 dan Pasal 108 Undang-Undang PT No. 40 Tahun 2007", Simbur Cahaya, No. 41 Tahun XV, Januari 2010, hlm. 1458; Paripurna P. Sugarda, "Pengelolaan Perusahaan yang Baik: Apakah Hanya Etika Bisnis atau juga Persyaratan Hukum?", J urnal Hukum Bisnis, Volume 14, J uli 2001, hlm. 61; dan Subiharta, "Ultra Vires" dan Good Corporate Governance" dalam Perspektif UU Nomor 40 Tahun 2007 tentang Perseroan Terbatas", Varia Peradilan, Tahun XXV No. 294 Mei 2010, hlm. 86. secara lebih konkrit asas-asas hukum GCG dalam peraturan internal perusahaan (self regulation) dan menerapkannya dalam praktik terbaik (best practices) ${ }^{15}$ sesuai dengan keadaan dan budaya perusahaannya (corporate culture). ${ }^{16}$

\section{Persyaratan, Prosedur Hukum, dan Ruang Lingkup Pemeriksaan Perseroan Terbatas}

Norma-norma hukum dalam Pasal 138 ayat (2) jo. Pasal 139 ayat (1) UU No. 40 Tahun 2007 mengharuskan pemeriksaan PT berdasarkan penetapan pengadilan negeri, sesuai dengan fungsi pengawasan lembaga peradilan ${ }^{17}$ dalam melindungi RUPS, direksi dan/atau dewan komisaris, baik secara organisasional (organ PT) maupun individual (personel dari organ PT), dari perbuatan-perbuatan pemegang saham dan/atau pihak ketiga yang sewenang-wenang atau "tindakan menghakimi sendiri" (eigenrichting). ${ }^{18}$ Perkara pemeriksaan PT adalah perkara perdata umum yang termasuk wewenang atau kompetensi absolut peradilan umum. Oleh karena itu, pengadilan yang berwenang (kompetensi relatif) menetapkan dapat atau tidak dapatnya dilakukan pemeriksaan PT adalah pengadilan negeri yang daerah hukumnya meliputi tempat kedudukan PT.

15 Menurut Colin Law \& Patricia Wong, GCG memuat prinsip-prinsip transparansi, akuntabilitas, keadilan, dan pertanggungjawaban yang dipraktikkan dengan kombinasi antara peraturan hukum, undang-undang non legisla-tif, best practices, dan self regulation. Colin Law \& Patricia Wong, "Corporate Governance: A Comparative Analysis Between The UK and China", International Company and Commercial Law Review, Vol. 16 (9), 2005, hlm. 350,

16 GCG mempromosikan etika bisnis yang mengarahkan peng-elola perusahaan untuk mengeliminasi budaya korupsi, suap-menyuap dan perilaku curang lainnya. Perhatikan. Meria Utama, "The Implementation of Good Corporate Governance in Indonesian Company", Simbur Cahaya, No. 44 Tahun XVI J anuari 2011, hlm. 2285.

17 Tugas lembaga peradilan dilakukan oleh hakim di pengadilan yang memberikan keputusan hukum yang akan berlaku sebagai kaidah hukum, yang berpojak pada koridor hukum, berdasarkan realitas sosial dan menjunjung tinggi perikemanusiaan. Cermati, Abdul Hakim Garuda Nusantara, "Kualitas Putusan Pengadilan Niaga", Jurnal Hukum Bisnis, Volume 22-No. 4-Tahun 2003, hlm. 23.

18 Lihat penjelasan tentang eigenrichting pada Sudikno Mertokusumo. op. cit., hlm. 2 dan 3; dan Agus Sudaryanto, "Fenomena Penghakiman Massa Dalam Perspektif Hukum Dan Ekonomi", Mimbar Hukum, Vol. X Nomor 36, Tahun 2000, hal 108. 
Lalu, siapakah yang dapat mengajukan permohonan pemeriksaan PT ke pengadilan negeri? Menurut Pasal 138 ayat (3) UU No. 40 Tahun 2007, satu orang pemegang saham saja mempunyai legal standing, sehingga boleh mengajukan permohonan pemeriksaan PT dalam kapasitasnya mewakili para pemegang saham lainya, dengan syarat mewakili paling sedikit $1 / 10$ (satu persepuluh) bagian dari jumlah seluruh saham dengan hak suara. Selain itu, beberapa pemegang saham juga boleh mengajukan permohonan pemeriksaan PT dengan syarat, yaitu dalam kapasitasnya memenuhi batas minimal kepemilikan saham sebagaimana ditentukan dalam Pasal 138 ayat (3) UU No. 40 Tahun 2007 tersebut di atas. Selanjutnya, pihak lain juga mempunyai legal standing atau hak mengajukan permohonan pemeriksaan PT dalam kapasitasnya sebagai "pribadi", dengan syarat: peraturan perundang-undangan sendiri yang memberikan hak itu kepada yang bersangkutan; atau berdasarkan perjanjian antara pihak lain itu dengan PT, di mana dalam satu di antara sejumlah klausula dalam perjanjian itu, memberikan wewenang kepadanya untuk mengajukan permohonan pemeriksaan PT. Berikutnya, kejaksaan juga mempunyai legal standing atau hak mengajukan permintaan pemeriksaan PT dalam kapasitasnya mewakili "kepentingan umum", dalam makna "kepentingan bang-sa dan negara dan/atau kepentingan masyarakat". ${ }^{19}$ Dengan demikian, UU No. 40 Tahun 2007 tidak memberikan legal standing atau hak mengajukan permohonan pemeriksaan PT kepada anggota direksi atau dewan komisaris, kecuali anggota direksi itu pemegang saham, sehingga dia berhak mengajukan permohonan pemeriksaan PT dalam statusnya sebagai pemegang saham, bukan dalam kapasitasnya sebagai anggota direksi atau dewan komisaris.

Pasal 138 ayat (3) huruf c UU No. 40 Tahun 2007 memberikan wewenang kepada kejaksaan sebagai "peminta" (bukan pemohon)

19 Lihat penjelasan mengenai makna "kepentingan umum" pada Y. Warella, Kepentingan Umum dan Kepentingan Perseorangan, "Dialogue" JIAKP, Vol. 1, No. 3, September 2004, Hal 382-386. pemeriksaan PT. ${ }^{20}$ Wewenang kejaksaan yang di berikan oleh UU No. 40 Tahun 2007 adalah bentuk dan isi "wewenang lain" selain di bidang penun-tutan sebagaimana diatur dalam Pasal 2 ayat (1) Undang-Undang Nomor 16 Tahun 2004 tentang Kejaksaan (selanjutnya disingkat UU No. 16 Tahun 2004). Selanjutnya, menurut Pasal 30 UU No. 16 Tahun 2004, di bidang perdata dan tata usaha negara, kejaksaan dengan kuasa khusus dapat bertindak baik di dalam atau di luar peng-adilan untuk dan atas nama negara atau pemerintah, sehingga kejaksaan sebagai advokat negara/ pemerintah harus berdasarkan surat kuasa khusus jika akan bertindak di depan pengadilan negeri sebagai peminta pemeriksaan PT. Konsekuensi logisnya, adalah kejaksaan harus aktif memantau dan mengawasi pengelolaan seluruh PT-PT di Indonesia untuk mengetahui ada atau tidak adanya perbuatan melawan hukum yang dilakukan oleh PT-PT itu yang menimbulkan kerugian bagi kepentingan bangsa dan negara dan/ atau masyarakat.

Penting diperhatikan bahwa permohonan pemeriksaan PT, menurut Penjelasan atas Pasal 138 ayat (4) UU No. 40 Tahun 2007, hanya dapat diajukan setelah pemohon terlebih dahulu meminta secara langsung data atau keterangan yang dibutuhkannya yang harus didasarkan atas "alasan yang wajar" dan "itikad baik" kepada PT dalam RUPS, tetapi PT tidak memberikan data atau keterangan tersebut. Ini berarti bahwa jika pemohon telah memperoleh data atau keterangan dari PT yang diminta oleh pemohon yang menguatkan dugaan terjadinya perbuatan

20 Seharusnya, dalam perkara permohonan pemeriksaan $\mathrm{PT}$, pemegang saham dan pihak ketiga yang berkepentingan disebut dengan "pemohon", sedangkan kejaksaan disebut "peminta, karena kedudukan hukum kejaksaan dalam perkara pemeriksaan PT adalah mewakili kepentingan umum, yang mencakup kepentingan bangsa dan negara dan/atau masyarakat, sehingga sejajar atau bukan subordinasi dari pengadilan negeri atau lembaga penegak hukum lainnya dalam penegakan hukum, termasuk hukum keperdataan. Bandingkan dengan penyebutan kejaksaan dengan istilah "peminta" dan pihak PT disebut dengan istilah "terminta" dalam perkara pemeriksaan yayasan sesuai dengan Pasal 53 ayat (3) UU No. 16 Tahun 2001 jo. UU No. 28 Tahun 2004 tentang Yayasan. Cermati Muhammad Syaifuddin, "Pemeriksaan Yayasan: Pengaturan, Inkonsistensi, dan Kemenduaan Hukumnya dalam UU No. 16/2001 jo. UU No. 28/2004", Simbur Cahaya, No. 39 Tahun XIV Mei 2009. 
mela-wan hukum sebagai bentuk penyimpangan dalam pengelolaan PT sebagaimana dimaksud oleh Pasal 138 ayat (1) UU No. 40 Tahun 2007, maka pemohon tidak dapat lagi mengajukan permohonan pemeriksaan PT. Sebaliknya, jika pemohon belum pernah mengajukan permintaan secara langsung kepada PT mengenai data atau keterangan yang dibutuhkannya, maka tertutup hak pemohon mengajukan permohonan pemeriksaan PT. Syarat formil yang ditentukan dalam Pasal 138 ayat (4) UU No. 40 Tahun 2007 hanya berlaku dan diterapkan kepada pemegang saham, sehingga tidak berlaku kepada pihak ketiga atau kejaksaan. Oleh karena itu, pihak lain atau kejaksaan dapat langsung mengajukan permohonan atau permintaan pemeriksaan PT tanpa harus terlebih dahulu melakukan upaya memohon atau meminta secara langsung data atau keterangan dari PT.

Menurut M. Yahya Harahap, permohonan pemeriksaan PT yang diajukan oleh pemohon (dalam hal ini: pemegang saham) yang melanggar syarat formil yang ditentukan dalam Pasal 138 ayat (4) UU No. 40 Tahun 2007, adalah permohonan yang mengandung cacat formil. Ditinjau dari segi teknis yudisial, permohonan itu dikategori sebagai permohonan yang "prematur" yang mengakibatkan permohonan tidak dapat diterima (niet ontvankelijk verklaard, to declare inadmissable).

Berikutnya, Pasal 138 ayat (2) UU No. 40 Tahun 2007 mengharuskan permohonan pemeriksaan PT diajukan secara tertulis (verzoekschri$\mathrm{ft}$ ), bukan secara lisan (mondeling, verbal). Kepentingan hukum (posita) yang menjadi alasan hukum permohonan pemeriksaan PT menurut Pasal 138 ayat (1) UU No. 40 Tahun 2007, yaitu terdapatnya dugaan perbuatan melawan hukum sebagai bentuk penyimpangan dalam pengelolaan PT yang dilakukan oleh PT, anggota direksi atau dewan komisaris yang merugikan PT, pemegang saham atau pihak ketiga.

Selain itu, permohonan pemeriksaan PT juga harus menguraikan secara tegas, jelas dan konkrit petitum ${ }^{21}$ yang relevan dengan per-

${ }^{21}$ Lihat penjelasan mengenai Petitum atau tuntutan, pada Sudikno Mertokusumo, op.cit., hlm. 55; dan Yudhi Se- mohonan itu sendiri. Berdasarkan alasan yang dihubungkan dengan tujuan permohonan pemeriksaan PT menurut Pasal 138 UU No. 40 Tahun 2007, serta memerhatikan pasal-pasal lainnya dalam UU No. 40 Tahun 2007 yang mengatur pemeriksaan PT (vide Pasal 139, Pasal 140 dan Pasal 141), maka petitum yang relevan dengan itu adalah: Pertama, meminta agar pengadilan negeri menerbitkan penetapan pemeriksaan terhadap PT; kedua: meminta agar pengadilan mengangkat 1 (satu) atau 3 (tiga) orang ahli melakukan pemer-iksaan PT; ketiga: meminta agar jangka waktu pemeriksaan oleh ahli, paling lama 30 (tiga puluh) atau 60 (enam puluh) hari, serta memerintahkan ahli melaporkan hasil pemeriksaan paling lambat dalam jangka waktu tersebut; keempat: memerintahkan setiap anggota direksi, anggota dewan komisaris dan karyawan PT memberi segala keterangan yang diperlukan dalam pelaksanaan pemeriksaan; kelima: membebankan segala biaya pemeriksaan kepada PT.

Surat permohonan pemeriksaan PT setelah didaftarkan di kepaniteraan pengadilan negeri, akan diperiksa oleh hakim dalam persidangan yang terbuka untuk umum. Pemegang saham atau pihak ketiga yang berkepentingan sebagai pemohon dan kejaksaan sebagai peminta wajib membuktikan dalil-dalil dugaannya. Sebaliknya, pihak PT dan/atau anggota direksi atau dewan komisaris sebagai termohon atau terminta juga wajib membuktikan dalil-dalil sanggahannya. Selanjutnya, pengadilan negeri akan memberikan putusan dalam bentuk penetapan dengan memertimbangkan alat-alat bukti dan fakta-fakta hukum yang terungkap di persidangan. Jika permohonan atau permintaan pemeriksaan PT dikabulkan oleh ketua pengadilan negeri, maka ketua pengadilan negeri, berdasarkan Pasal 139 ayat (3) UU No. 40 Tahun 2007, dalam penetapannya harus memuat diktum, yaitu: mengangkat paling banyak 3 (tiga) "orang yang ahli" sebagai "pemeriksa" untuk melakukan pemeriksaan PT untuk mendapat-

tiawan dan Boedi Djatmiko Hadiatmodjo, Cacat Yuridis Dalam Prosedur Sebagai Alasan Pembatalan Sertifikat Hak Atas Tanah Oleh Pradilan Tata Usaha Negara, J urnal Equality, Vol. 13 Nomor 1, Februari 2008, hal 4. 
kan data atau keterangan yang diperlukan; menetapkan jangka waktu pemeriksaan paling lambat 90 (sembilan puluh) hari terhitung sejak tanggal pengangkatan; memerintahkan ahli membuat dan menyampaikan Laporan Hasil Pemeriksaan kepada Ketua Pengadilan dalam jangka waktu yang tidak boleh lebih dari 90 (sembilan puluh) hari; menetapkan atau menentukan biaya pemeriksaan. Kemudian, ahli (pemeriksa) yang telah ditetapkan berdasarkan penetapan hakim pengadilan negeri sesuai dengan Pasal 139 ayat (3) UU No. 40 Tahun 2007, wajib melakukan pemeriksaan PT. Dalam rangka melaksanakan tugas pemeriksaan PT, UU No. 40 Tahun 2007 memberikan wewenang kepada orang yang ahli sebagai pemeriksa PT untuk memeriksa semua dokumen dan kekayaan PT yang dianggap perlu (vide Pas-al 139 ayat (5)) dan memeriksa setiap anggota direksi, anggota dewan komisaris dan semua karyawan PT yang dianggap perlu oleh ahli sebagai pemeriksa (vide Pasal 139 ayat (6)).

Tahap akhir, berdasarkan Pasal 140 UU No. 40 Tahun 2007, ahli (pemeriksa) wajib menyampaikan laporan hasil pemeriksaan PT kepada ketua pengadilan negeri dalam jangka waktu sebagaimana ditentukan dalam penetapan pengadilan negeri untuk pemeriksaan PT paling lambat 90 (sembilan puluh) hari terhitung sejak tanggal pengangkatan orang yang ahli sebagai pemeriksa PT tersebut. Berikutnya, ketua pengadilan negeri memberikan salinan laporan hasil pemeriksaan PT kepada pemegang saham atau pihak ketiga yang berkepentingan sebagai pemohon atau kejaksaan sebagai peminta. Jadi, pengadilan tidak campur tangan lagi terhadap hasil pemeriksaan PT itu, karena pengadilan bersikap pasif, dalam arti tidak berwenang memberikan penetapan lebih lanjut atau rekomendasi kepada pemohon (pemegang saham atau pihak ketiga) atau peminta (kejaksaan) untuk melakukan tindakan hukum atau upaya hukum tertentu yang berkaitan dengan hasil pemeriksaan PT. Ini berarti bahwa laporan hasil pemeriksaan PT itu berupa bahan bagi pemohon atau peminta untuk menentukan sikap apakah dia akan mengajukan gugatan perdata ber- dasarkan Pasal 1365 KUH Perdata kepada PT, anggota direksi atau dewan komisaris jika berdasarkan hasil pemeriksaan cukup fakta tentang terjadinya perbuatan melawan hukum yang menimbulkan kerugian bagi pemegang saham, pihak ketiga atau kepentingan umum. Selain itu, pemohon (pemegang saham atau pihak ketiga) atau peminta (kejaksaan) harus melaporkan kepada kepolisian jika menurut hasil pemeriksaan itu terdapat unsur-unsur tindak pidana penggelapan berdasarkan Pasal $372 \mathrm{KUH}$ Pidana atau penipuan berdasarkan Pasal 378 KUH Pidana.

Ketua pengadilan negeri, menurut Pasal 139 ayat (1) UU No. 40 Tahun 2007, berwenang menolak permohonan pemeriksaan PT yang diajukan oleh pemohon (pemegang saham atau pi-hak ketiga) atau permintaan pemeriksaan PT ya-ng diajukan oleh peminta (kejaksaan). Menurut M. Yahya Harahap, jika prinsip hukum pembuktian dikaitkan dengan Pasal 139 ayat (2), berarti penolakan permohonan oleh Ketua pengadilan negeri, karena pemohon tidak dapat membuktikan adanya dugaan perbuatan melawan hukum yang dilakukan oleh PT, anggota direksi atau dewan komisaris. Sebaliknya, Ketua Pengadilan Negeri menemukan fakta atau dapat membuktikan, permohonan yang diajukan diselubungi dengan itikad tidak baik (te kwader trouw, bad faith). Misalnya, permohonan diajukan untuk mengganggu kegiatan PT. J adi, ketua pengadil-an negeri berwenang menolak permohonan atau permintaan pemeriksaan PT yang diajukan oleh pemohon (pemegang saham atau pihak ketiga), atau peminta (kejaksaan) berdasarkan atas pertimbangan, yaitu: permohonan tidak didasarkan atas alasan yang wajar dan/ atau tidak dilakukan dengan itikad baik.

\section{Inkonsistensi dan Kemenduaan Hukum seba- gai Wujud Kelemahan Pengaturan Hukum Pe- meriksaan Perseroan Terbatas}

Ide normatif Pasal 139 ayat (3) UU No. 40 Tahun 2007 yang mengharuskan pemeriksaan PT berdasarkan penetapan pengadilan negeri, karena penetapan pengadilan negeri itu merupakan keputusan hukum atas dasar permohonan 
dari pemohon (pemegang saham atau pihak ketiga) atau permintaan (kejaksaan). Namun, secara matril penetapan pengadilan negeri hanya semata-mata untuk menentukan orang yang ahli yang diangkat sebagai pemeriksa PT, sehingga tid-ak memutuskan bersalah atau tidak bersalahnya PT atau anggota direksi atau dewan komisaris yang diduga melakukan perbuatan melawan hukum sebagai bentuk penyimpangan dalam pengelolaan PT sebagaimana dimaksud oleh Pasal 138 ayat (1) UU No. 40 Tahun 2007.

UU No. 40 Tahun 2007 tidak menentukan kriteria "ahli", tetapi hanya menjelaskan secara umum bahwa yang dimaksud dengan "ahli" adalah "Orang yang mempunyai keahlian dalam bidang yang akan diperiksa" (vide Penjelasan atas Pasal 139 ayat (3)). Selain itu, Pasal 139 ayat (4) UU No. 40 Tahun 2007 hanya memuat keten-tuan larangan bagi setiap anggota direksi, anggota dewan komisaris, karyawan PT, konsultan, dan akuntan publik yang telah ditunjuk oleh PT tidak dapat diangkat sebagai ahli". J adi, terdapat kemenduaan hukum berupa norma terbuka (open texture) tentang kriteria ahli dalam Pasal 139 ayat (3) UU No. 40 Tahun 2007, yang dapat menimbulkan kemenduaan dalam penerapan hu-kumnya.

Secara yuridis, setiap anggota direksi, anggota dewan komisaris, dan semua karyawan PT "diharuskan" oleh Pasal 139 ayat (6) UU No. 40 Tahun 2007 untuk memberikan data atau keterangan yang diperlukan untuk pemeriksaan PT kepada orang yang ahli sebagai pemeriksa PT. Namun, UU No. 40 Tahun 2007 ternyata tidak mengatur sanksi hukumnya kepada mereka yang menolak memberikan data atau keterangan dimaksud, sehingga inkonsisten dengan asas manfaat, karena norma-norma hukum dalam Pasal 139 ayat (5) dan ayat (6) UU No. 40 Tahun 2007 tidak mempunyai daya kerja normatif, sebab orang yang ahli sebagai pemeriksa PT tidak mempunyai upaya hukum apapun dan tidak dapat meminta bantuan hukum kepada polisi, jaksa dan hakim untuk memaksa setiap anggota direksi, anggota dewan komisaris, dan semua karyawan PT agar kooperatif selama proses pe- meriksaan PT, karena tidak ada dasar hukumnya dalam UU No. 40 Tahun 2007. J adi, pemeriksaan PT sangat tergantung kepada itikad baik dari setiap anggota direksi, anggota dewan komisaris, dan semua karyawan PT yang bersangkutan.

Kemenduaan hukum berupa norma kabur (vague norm) juga terdapat dalam prosedur hukum pascapemeriksaan PT, karena orang yang ahli sebagai pemeriksa PT, setelah melakukan pemeriksaan PT, tidak diberikan wewenang yang jelas dan konkrit oleh UU No. 40 Tahun 2007 untuk menyatakan benar atau salah dugaan terjadinya perbuatan melawan hukum sebagai bentuk penyimpangan pengelolaan PT sebagaimana dimaksud oleh Pasal 138 ayat (1) UU No. 40 Tahun 2007. Selain itu, UU No. 40 Tahun 2007 juga tidak mengatur kekuatan mengikat laporan hasil pemeriksaan PT terhadap pemegang saham atau pihak ketiga yang berkepentingan sebagai pemohon dan kejaksaan sebagai peminta, serta pihak PT atau anggota direksi atau dewan komisaris sebagai termohon atau terminta.

Norma hukum dalam Pasal 138 ayat (7) UU No. 40 Tahun 2007 mewajibkan orang yang ahli sebagai pemeriksa PT untuk merahasiakan hasil pemeriksaan PT kepada pihak lain. Jadi, secara a contrario, dapat ditafsirkan bahwa orang yang ahli sebagai pemeriksa PT dilarang oleh Pasal 138 ayat (7) UU No. 40 Tahun 2007 Pasal 138 ayat (7) UU No. 40 Tahun 2007 untuk mengumumkan atau memberitahukan hasil pemeriksaan PT kepada pihak lain. Namun, ketentuan imperatif ini (secara a contrario dapat pula disebut ketentuan larangan) ternyata tidak dise-rtai dengan sanksi hukum terhadap orang yang ahli sebagai pemeriksa PT yang melakukan pela-nggaran terhadap kewajiban hukumnya (secara a contrario dapat pula disebut melakukan pela-nggaran terhadap ketentuan larangannya).

Berikutnya, UU No. 40 Tahun 2007 memberikan tugas administratif (nonyustisial) sebagai "tugas tambahan" kepada ketua pengadilan negeri di tempat kedudukan PT, untuk menerima laporan hasil pemeriksaan PT yang 
harus disampaikan oleh orang yang ahli sebagai pemeriksa PT paling lambat 90 (sembilan puluh) terhitung sejak tanggal pengangkatan orang yang ahli sebagai pemeriksa PT. Kemudian, berdasarkan Pasal 140 ayat (2) UU No. 40 Tahun 2007, ketua pengadilan negeri memberikan salinan laporan hasil pemeriksaan PT itu baik kepada pemegang saham atau pihak ketiga yang berkepentingan sebagai pemohon dan kejaksaan sebagai peminta maupun pihak PT atau anggota direksi atau dewan komisaris sebagai termohon atau terminta dalam jangka waktu paling lambat 14 (empat belas) hari terhitung sejak tanggal laporan hasil pemeriksaan PT diterima. Norma hukum dalam Pasal 140 ayat (2) UU No. 40 Tahun 2007 isinya berlebihan (overbodig), karena setelah pemeriksaan PT selesai dilakukan, masih memerlukan intervensi (campur tangan) ketua pengadilan negeri untuk menerima dan memberikan hasil pemeriksaan PT kepada pihak-pihak yang berkepentingan. Selain itu, juga terdapat inkonsistensi, karena ketentuan limitatif ini ternyata tidak mengatur akibat hukum dan upaya hukum yang dapat dilakukan oleh pihak-pihak yang dirugikan (utamanya pemohon atau peminta pemeriksaan PT, serta orang yang ahli sebagai pemeriksa PT) atau mungkin sanksi hukum yang dapat diterapkan kepada ketua pengadilan negeri yang lalai atau tidak melakukan atau terlambat melakukan kewajiban hukumnya memberikan salinan laporan hasil pemeriksaan PT dalam jangka waktu yang telah ditentukan oleh undang-undang, baik kepada pemegang saham atau pihak ketiga yang berkepentingan sebagai pemohon dan kejaksaan sebagai peminta maupun pihak PT atau anggota direksi atau dewan komisaris sebagai termohon atau terminta.

\section{Gagasan Pengaturan Hukum Ideal Pemeriksa- an Perseroan Terbatas di Masa yang Akan Datang}

Pemeriksaan PT berdasarkan UU No. 40 Tahun 2007 yang mengandung banyak inkonsistensi dan kemenduaan hukum tidak akan dapat menjamin kepastian hukum, ${ }^{22}$ sehingga tidak akan dapat bermanfaat secara praktikal. Idealnya, harus ada perbaikan pengaturan hukum pemeriksaan PT dalam UU No. 40 Tahun $2007^{23}$ dalam upaya mewujudkan pengelolaan perusahaan yang baik di masa yang akan datang, yang prinsip-prinsipnya mencakup beberapa hal.

Pertama, adalah penguatan asas kepastian hukum dan asas kemanfaatan (selain asas keadilan) sebagai dasar filosofis pendirian dan pengelolaan PT, termasuk pemeriksaan PT yang harus dinyatakan secara tegas dalam satu pasal khusus, untuk kemudian dikonkritisasi hukum (dijabarkan secara normatif) dalam pasal-pasal lainnya dalam suatu sistem hukum PT. Asas hukum bukan norma hukum yang dapat dipakai langsung dalam praktik, sehingga isinya perlu di bentuk lebih konkrit. ${ }^{24}$ Artinya, asas kepastian hukum dan asas manfaat (selain asas keadilan) dirumuskan secara abstrak dan umum, kemudian dikonkritisasi hukum menjadi norma hukum positif, sehingga dapat digunakan dalam praktik hukum di pengadilan. ${ }^{25}$

Kedua, adalah Perbaikan (mencakup: perubahan dan penambahan) norma-norma hukum pemeriksaan PT yang mengacu kepada logika-logika aturan hukum, antara lain, (a) Jika suatu aturan hukum memberikan wewenang tertentu kepada subjek hukum tertentu, maka harus ada kejelasan wewenang dan kriteria konkrit subjek hukum tertentu yang diberikan wewenang. Logika aturan hukum ini harus men-

22 Kepastian hukum, menurut Shidarta berintikan prediktabilitas, yakni kemampuan memersepsikan "an individual ought to behave in certain way". Shidarta, "Minosmer dalam Nomenklatur Positivisme hukum", Era Hukum, No. 2 TH. 11/-J anuari 2004, hlm. 2.

23 Lihat penjelasan tentang membangun undang-undang yang ideal pada M. Laica Marzuki, "Membangun UndangUndang yang Ide-al", J urnal Legislasi Indonesia, Vol. 4 No. 2-J uni 2007, hlm. 1

24 Mahadi, 1989, Falsafah Hukum Suatu Pengantar, Bandung: PT. Citra Aditya Bakti, hlm. 119. Bandingkan dengan Peter Mahmud Marzuki, "Batas-batas Kebebasan Berkontrak", Yur-idika, Vol. 18, No. 3, Mei 2003.

25 Menurut Erman Rajagukguk, Undang-Undang PT yang dapat menciptakan predictability, stability, dan fairness adalah syarat mutlak untuk berperannya Undang-Undang ini dalam mendorong pembangunan ekonomi. Erman Rajagukguk, "Pengelolaan Perusahaan yang Baik: Tanggung Jawab Pemegang Saham, Komisaris, dan Dir-eksi", Jurnal Hukum Bisnis, Volume 26-No. 3-Tahun 2007, hlm. 30. 
jadi acuan dalam merumuskan norma hukum yang tegas dan konkrit sebagai dasar hukum pemberian wewenang kepada orang yang ahli sebagai pemeriksa PT untuk menyatakan benar atau tidak benar dugaan terjadinya perbuatan mela-wan hukum sebagai bentuk penyimpangan dalam pengelolaan PT yang dilakukan oleh RUPS, direksi dan/atau dewan komisaris, baik secara organisasional (organ PT) maupun individual (personel dari organ PT), dan penentuan kriteria konkrit "orang yang ahli" yang berwenang melakukan pemeriksaan PT berdasarkan pen-etapan pengadilan (perbaikan norma hukum dalam Pasal 139 ayat (3)). Kriteria dasar ahli sebagaimana ditegaskan oleh $\mathrm{M}$. Yahya Harahap dapat dijadikan titik tolak dalam menentukan kriteria ahli, yaitu: memiliki kompetensi khusus yang tidak dimiliki orang biasa (ordinary people), berupa kecakapan (skill) yang diperoleh dari hasil pendidikan (education), latihan (training) maupun pengalaman (experience); (b) J ika suatu aturan hukum mengharuskan adanya prosedur hukum tertentu, maka harus ada jangka waktu pelaksanaan, akibat hukum, upaya hukum, bahkan sanksi hukum atas pelanggaran prosedur hukum tertentu tersebut. Logika aturan hukum ini harus menjadi acuan dalam merumuskan norma hukum yang jelas dan konkrit yang menentukan akibat hukum dan upaya hukum yang dapat dilakukan oleh pihak-pihak yang dirugikan (utamanya pemohon atau peminta pemeriksaan PT, serta orang yang ahli sebagai pemeriksa PT), bahkan mungkin sanksi hukum (administratif) yang dapat diterapkan kepada ketua pengadilan negeri yang lalai atau terlambat melakukan atau tidak melakukan kewajiban hukumnya memberikan salinan laporan hasil pemeriksaan PT itu, baik kepada pemegang saham atau pihak ketiga yang berkepentingan sebagai pemohon dan kejaksaan sebagai peminta maupun pihak PT atau anggota direksi atau dewan komisaris sebagai termohon atau terminta (perbaikan norma hukum dalam Pasal 140 ayat (2)); (c) J ika suatu aturan hukum mewajibkan subjek hukum tertentu melakukan perbuatan hukum tertentu dalam hubunganhubungan hukum tertentu pula, maka harus ada sanksi hukum kepada subjek hukum tertentu yang melalaikan kewajiban hukumnya tersebut. Logika aturan hukum ini harus menjadi acuan dalam merumuskan norma hukum yang jelas dan konkrit yang mengatur bentuk dan mekanisme pengenaan sanksi hukum kepada: setiap anggota direksi atau dewan komisaris, dan semua karyawan PT yang menolak (tidak melaksanakan) kewajiban hukum memberikan data atau keterangan yang diperlukan oleh orang yang ahli sebagai pemeriksa PT untuk melakukan pemeriksaan PT (perb-aikan norma hukum dalam Pasal 139 ay-at (4)); dan orang yang ahli sebagai pemeriksa PT yang mengumumkan atau memberitahukan hasil pemeriksaan PT yang telah dilakukannya kepada pihak lain (perbaikan norma hukum dalam Pasal 138 ayat (7)); (d) J ika suatu aturan hukum memberikan hak kepada subjek hukum tertentu untuk mengajukan permohonan atau permintaan tertentu kepada pengadilan, maka harus ada kekuatan mengikat penetapan pengadilannya terhadap subjek hukum tertentu yang mengajukan permohonan atau permintaan tersebut. Logika aturan hukum ini harus menjadi acuan dalam mengatur kekuatan mengikat (kekuatan hukum) hasil pemeriksaan PT yang dilakukan oleh orang yang ahli sebagai pemeriksa PT berdasarkan penetapan pengadilan negeri terhadap pemegang saham atau pihak ketiga yang berkepentingan sebagai pemohon dan kejaksaan sebagai peminta pemeriksan PT kepada pengadilan negeri. Seharusnya ada ketentuan imperatif yang menegaskan kewajiban pemohon atau peminta untuk menindaklanjuti (merespon) laporan hasil pemeriksaan PT yang dilakukan oleh orang yang ahli sebagai pemeriksa PT yang membenarkan dugaan terjadinya perbuatan melawan hukum yang dilakukan oleh organ PT (RUPS, direksi dan dewan komisaris) atau personel dari organ PT (anggota direksi atau dewan komisaris) sebagai bentuk penyimpangan dalam pengelolaan PT tersebut tidak hanya menimbulkan kerugian bagi pemegang saham, pihak ketiga atau kepentingan umum, tetapi juga terdapat unsur-unsur tindak pidana penggelapan (vide Pasal $372 \mathrm{KUH}$ Pidana) atau penipuan (vide Pasal $378 \mathrm{KUH}$ Pi- 
dana) (perbaikan norma hukum dalam Pasal 139 ayat (7)).

\section{Penutup \\ Simpulan}

UU No. 40 Tahun 2007 (vide Pasal 138-Pasal 141) memuat pengaturan hukum pemeriksaan PT, yang bertujuan menemukan dan menerang-benderangkan kebenaran dugaan terjadinya perbuatan melawan hukum sebagai bentuk penyimpangan yang dilakukan oleh organ PT (RUPS, direksi dan dewan komisaris) atau personel dari organ PT (anggota direksi atau dewan komisaris) dalam pengelolaan PT yang merugikan pemegang saham, pihak ketiga atau kepentingan umum. Namun, persyaratan dan prosedur hukum, serta ruang lingkup pemeriksaan PT yang diatur dalam UU No. 40 Tahun 2007 mengandung banyak inkonsistensi dan kemenduaan hukum (norma kabur dan norma terbuka), sehingga norma-norma hukum positif pemeriksaan PT tidak memadai untuk menjelaskan dan mengarahkan tercapainya tujuan pemeriksaan PT, yang menimbulkan ketidakpastian hukum, yang dapat berakibat ketidakmanfaatan hukum secara praktikal, yang pada akhirnya dapat menjadi hambatan (constrain) dalam upaya mewujudkan pengelolaan perusahaan yang baik. Oleh karena itu, gagasan pengaturan hukum ideal pemeriksaan PT dalam upaya mewujudkan pengelolaan perusahaan yang baik di masa yang akan datang perlu memperhatikan prinsip-prinsip yang mencakup: pertama, penguatan asas kepastian hukum dan asas kemanfaatan hukum (selain asas keadilan) yang dikonkritisasi dalam norma-norma hukum positif mengenai pendirian, pengelolaan, pemeriksaan dan pascapemeriksaan PT, sebagai suatu sistem; kedua, perbaikan norma-norma hukum positif mengenai pemeriksaan PT yang konsisten dan tidak mendua, dengan mengacu kepada logika-logika aturan hukum.

\section{Daftar Pustaka}

Adjie, Habib. "Tanggung Jawab Sosial Perusahaan". J urnal Hukum Bisnis, Vol. 27-No. 1-Tahun 2008;
Alias, Jimmy E. "Peran Manajemen Risiko Strategik dalam Mendukung Good Corporate Governance". J urnal Hukum Bisnis, Volume 23 No. 3-Tahun 2004;

Badruzzaman, Mariam Darus. 2001. Kompilasi Hukum Peri-katan. Bandung: PT. Citra Aditya Bakti;

Harahap, M. Yahya. "Separate Entity, Limited Liability, dan Piercing the Corporate Veil". Jurnal Hukum Bisnis, Vol. 26-No. 3-Tahun 2007;

Ibrahim, Johnny. 2005. Teori dan Metode Penelitian Hukum Normatif. Malang: Bayu Media Publishing;

Isnaeni, M. "Hak Tanggungan sebagai Lembaga Jaminan dalam Kerangka Tata Hukum Indonesia". J urnal Hukum Ekonomi, Edisi V, Agustus 1996;

Khairandy, Ridwan. "Perseroan Terbatas sebagai Badan Hukum". Jurnal Hukum Bisnis, Vol. 26 No. 3 Tahun 2007;

Law, Colin \& Patricia Wong. "Corporate Governance: A Comparative Analysis Between The UK and China". International Company and Commercial Law Review, Vol. 16 (9), 2005;

Mahadi. 1989. Falsafah Hukum Suatu Pengantar. Bandung: PT. Citra Aditya Bakti;

Malik, Camelia. "Implikasi Adanya Komisaris Independen dalam Perseroan Berdasarkan UU No. 40 Tahun 2007". Jurnal Hukum Bisnis, Volume 26-No. 3 Tahun 2007;

Marzuki, M. Laica. "Membangun Undang-Undang yang Ide-al". J urnal Legislasi Indonesia, Vol. 4 No. 2-J uni 2007;

Marzuki, Peter Mahmud. "Batas-batas Kebebasan Berkontrak". Yuridika, Vol. 18, No. 3, Mei 2003;

Mertokusumo, Sudikno. 2006. Hukum Acara Perdata Indonesia. Yogyakarta: Liberty;

Nusantara, Abdul Hakim Garuda. "Kualitas Putusan Pengadilan Niaga". Jurnal Hukum Bisnis, Volume 22 No. 4-Tahun 2003;

Pramono, Nindyo. "Tanggung J awab Dan Kewajiban Pengurus PT (Bank) Menurut UU No. 40 Tahun 2007 Tentang Perseroan Terbatas". Buletin Hukum Perbankan dan Kebangsentralan, Vol. 05 Nomor 03, Desember 2007;

Rahardjo, Satjipto. 2000. Ilmu Hukum. Bandung: PT. Citra Aditya Bakti; 
Rajagukguk, Erman. "Pengelolaan Perusahaan yang Baik: Tanggung Jawab Pemegang Saham, Komisaris, dan Direksi". J urnal Hukum Bisnis, Volume 26 No. 3 Tahun 2007;

Salman, Radian. "Mahkamah Konstitusi dan Politik Hukum di Bidang Pemilihan Umum". Jurnal Konstitusi, Vol. II, No. 1, J uni 2009;

Setiawan, Yudhi dan Boedi Djatmiko Hadiatmodjo. "Cacat Yuridis Dalam Prosedur Sebagai Alasan Pembatalan Sertifikat Hak Atas Tanah Oleh Pradilan Tata Usaha Negara". J urnal Equality, Vol. 13 Nomor 1, Februari 2008;

Shidarta. "Minosmer dalam Nomenklatur Positivisme Hukum". Era Hukum, No. 2 TH. 11/ J anuari 2004;

Subiharta. "Ultra Vires" dan Good Corporate Governance" dalam Perspektif UU Nomor 40 Tahun 2007 tentang Perseroan Terbatas". Varia Peradilan, Tahun XXV No. 294 Mei 2010;

Sudaryanto, Agus. "Fenomena Penghakiman Massa Dalam Perspektif Hukum dan Ekonomi". Mimbar Hukum, Vol. X Nomor 36, Tahun 2000;

Sugarda, Paripurna P. "Pengelolaan Perusahaan yang Baik: Apakah Hanya Etika Bisnis atau juga Persyaratan Hukum?". J urnal Hukum Bisnis, Volume 14, J uli 2001;

Syaifuddin, Muhammad. "Pemeriksaan Yayasan: Pengaturan, Inkonsistensi, dan Kemenduaan Hukumnya dalam UU No. 16/ 2001 jo. UU No. 28/ 2004". Simbur Cahaya, No. 39 Tahun XIV Mei 2009;

. "Perspektif Global Penyelesaian Sengketa Investasi di Indonesia". De J ure, J urnal Syariah dan Hukum, Vol. 02 Nomor 01, J uni 2010;

------. "Tanggung Jawab Sosial Perusahaan: Perkembangan Teori dan Relevansinya dengan Tujuan Hukum Perusahaan". Simbur Cahaya, No. 31 Tahun XI, Mei 2006;

. "Wewenang Dewan Komisaris Mengurus Perseroan Terbatas: Analisis Rasio dan Implikasi Hukum Pasal 118 dalam Kaitannya dengan Pasal 1 angka 6 dan Pasal 108 Undang-Undang PT No. 40 Tahun 2007". Simbur Cahaya, No. 41 Tahun XV, J anuari 2010;

Tumbuan, Fred B.G. “Tugas dan Wewenang Organ Perseroan Terbatas Menurut UndangUndang Tentang Perseroan Terbatas". PPH Newsletters, Nomor 70, Septem-ber 2007;

Utama, Meria. "The Implementation of Good Corporate Governance in Indonesian Company". Simbur Cahaya, No. 44 Tahun XVI J anuari 2011;

Warella, Y. "Kepentingan Umum dan Kepentingan Perseorangan". "Dialogue" J IAKP, Vol. 1, No. 3, September 2004;

Yuniarti. "Kewenangan Notaris Membuat Akta Risalah Rapat Umum Pemegang Saham Luar Biasa tentang Perubahan Ang-garan Dasar Perseroan Terbatas". Repertorium, Vol. 1 No. 1 Mei-September 2010. 